\title{
The importance of Dentistry in COVID-19 pandemic and the role of saliva as a diagnostic tool
}

\section{A importância da Odontologia na pandemia do COVID-19 \\ e o papel da saliva como meio diagnóstico}

\author{
Nathalya Maria Vilela MOURA' ID https://orcid.org/0000-0003-4609-0868 \\ Amanda Ferreira GONZALEZ ${ }^{1}$ iD https://orcid.org/0000-0001-8611-7645 \\ Mario TABA JUNIOR ${ }^{1}$ iD https://orcid.org/0000-0002-7098-5090
}

\begin{abstract}
ABSCTRACT
News of the symptoms caused by a coronavirus in humans began to be documented in December 2019, when several cases of pneumonia caused by the virus occurred in China. Studies are showing the increasing role of saliva and oral cavity in the transmission of the virus, because the receptors of epithelial cells in this region play a critical role by allowing the virus to enter those cells. The standard method to diagnose the coronavirus is based on the collection of samples in the nasopharynx and oropharynx to detect viral RNA. However, this method results in the interaction between health care professionals and patients, which increases risk of transmission; moreover, this collection can be painful for the patient and cause bleeding. As an alternative, diagnosis can be made using saliva, which only requires patients to deposit the saliva sample in a sterile container. Thus, the objective of this literature review is to present the main forms of contagion and to describe the diagnosis tools, emphasizing the risk that dental professionals are exposed to and, therefore, the growing need for better and faster diagnostic methods for coronavirus, especially using saliva. Medline, PubMed, SciELO, and Bireme databases were used for the literature search with the descriptors: Salivary diagnosis, COVID-19, and Contagion. The review explored the scientific race to develop more effective forms of diagnosis, including saliva tests, and prevention methods taking into account time, accessibility, and cost-benefit and, as a consequence, the role of dentistry has been continuously increasing.
\end{abstract}

Indexing terms: Coronavirus infections. Diagnosis. Saliva.

\section{RESUMO}

As notícias dos sintomas causados pelo coronavírus nos seres humanos começaram a ser documentadas em Dezembro de 2019 , quando vários casos de pneumonia causados pelo vírus ocorreram na China. Estudos mostram o papel crescente da saliva e cavidade oral na transmissão do vírus, pois os receptores das células epiteliais nessa região desempenham um papel crítico ao permitir que o vírus entre nas células. O método padrão de diagnóstico do coronavírus se dá a partir da coleta de amostras na nasofaringe e orofaringe para detectar o RNA viral. Entretanto, esse método resulta na interação entre profissional e paciente, levando ao risco de transmissão e, além disso, essa coleta pode ser dolorida para o paciente e causar sangramentos. Como solução, surgiu o diagnóstico através da saliva, que necessita apenas que os pacientes a depositem em um recipiente estéril. Assim, o objetivo do presente trabalho é explicar, através de uma revisão da literatura, as principais formas de contágio e diagnóstico, enfatizando o alto risco que o profissional odontológico

\footnotetext{
$\boldsymbol{\nabla} \mathbf{v} \mathbf{v}$

1 Universidade de São Paulo, Faculdade de Odontologia de Ribeirão Preto, Departamento de Cirurgia Oral e Periodontia. Av. do Café - Subsetor Oeste, 11, 14040-904, Ribeirão Preto, SP, Brasil. Correspondence to: NMV Moura. E-mail: <nathalya_vilela@usp.br>.

Moura NMV, Gonzalez AF, Taba Junior M. The importance of Dentistry in COVID-19 pandemic and the role of saliva as a diagnostic tool. RGO, Rev Gaúch Odontol. 2021;69:e2021016. http://dx.doi.org/10.1590/1981-86372021001620200138
} 
sofre e, por isso, a crescente necessidade de melhores e mais rápidas formas de diagnóstico do coronavírus, especialmente através da saliva. Para a busca da literatura foram utilizadas os descritores: Diagnóstico salivar, COVID-19 e Contágio, com busca nas bases de dados Medline, Pubmed, Scielo e Bireme. Foi concluído que existe atualmente uma corrida científica para a criação de formas mais eficazes de diagnóstico e prevenção, levando em consideração tempo, acessibilidade e custo-benefício e, como consequência, a importância da odontologia vem crescendo continuamente.

Termos de indexação: Infecções por Coronavirus. Diagnóstico. Saliva.

\section{INTRODUCTION}

News of symptoms caused by a coronavirus in humans began to be noticed in December 2019, initiating worldwide concern after several cases of pneumonia were caused by the newly identified virus in Wuhan, China. The first nomenclature used by the World Health Organization (WHO) on January 12, 2020 to differentiate this virus was "2019-novel coronavirus" (2019-nCoV), but later that nomenclature was officially changed to "coronavirus disease 2019" (COVID-19). In addition to that, the International Committee's Coronavirus Study Group proposed another name that is also used today: SARS-CoV-2 which, along with "COVID-19", was first published on February $11,2020[1,2]$.

Assumptions stating the association of the first cases of COVID-19 with a seafood market in Wuhan, where the infection may have passed from animal to human. Thereafter, the other cases that emerged were the result of human-to-human transmission [2].

Genome sequencing of the virus was performed on January 7, 2020 when Chinese scientists isolated SARSCoV-2 from an infected patient. The virus spread quickly and in large proportions, reaching a total of 16,301,736 cases worldwide by August 27, 2020, including 650,069 confirmed deaths due to the pandemic $[2,3]$.

Coronaviruses are encapsulated positive-sense viruses with single-stranded RNA genomes that can reach 32 kilobases in length and are considered one of the viruses with the largest known genome. Coronaviruses were initially restricted to birds and mammals with impact on the agricultural industry due to lethal diseases resulting from contagion. Thus, originally, these viruses were considered enzootic infections, that is, limited only to their animal hosts. However, these infections crossed the barrier between humans and animals, and the major concern at the moment is the contagion in humans $[2,4,5]$.

The most documented symptoms in humans who contract the virus are fever, cough, fatigue, symptoms of gastrointestinal infections, muscle pain, sore throat, confusion, chest pain, headache, rhinorrhea, diarrhea, nausea, and vomiting. Older individuals and those with comorbidities (hypertension, chronic obstructive pulmonary disease, diabetes, cardiovascular diseases, among others) are more susceptible to infection and are at greater risk for the disease worsening, which may cause respiratory distress syndrome, septic shock, metabolic acidosis, coagulation dysfunction, and, finally, multiple organ failure $[1,6]$.

The coronavirus transmission occurs both by direct transmissions, such as coughing, sneezing, and inhalation of droplets, as well as by contact transmissions, such as ocular contact, saliva, and mucous membranes of nose and eyes. The latest studies defined that the virus can be detected in the gastrointestinal tissue, tears, feces, blood, and saliva from infected subjects. Based on epidemiological investigations, the virus incubation period is between 1 to 14 days and the peak of transmission occurs during the latency period when the infection is subclinical $[1,6,7]$.

The scientific community has revealed the growing role of saliva and oral cavity in the current pandemic situation, mostly after the discovery that the epithelial cells of the oral cavity demonstrate a wide expression of Angiotensin-Converting Enzyme 2 (ACE2) receptors, which plays a critical role in allowing SARS-CoV-2 to enter cells [6].

The role of dentistry in early diagnosis of diseases has been growing and increasingly documented. Many diseases present oral signs and symptoms that, given the dentist's ability to perceive deviations from normality in the oral region, a more accurate diagnosis can be obtained and, consequently, early treatment options implemented before the disease worsens.

Autoimmune diseases (lupus erythematosus, Sjögren's syndrome, pemphigus vulgaris, Behcet's disease, among others), in addition to viral diseases (herpes, chickenpox, mononucleosis, rubella, among others), manifest in the oral cavity and are good examples of dental surgeons' role in diagnosis. Another relevant condition is the diagnosis of tumors originating in the oral cavity with involvement of other organs. The patient may be asymptomatic, which again indicates the importance of the dental surgeon in the early diagnosis when performing the 
routine exams of palpation and detection of physiological changes. For this reason, dental surgeons have gained an important role in detecting several pathological conditions [8-10].

The standard method for diagnosing coronavirus is based on the collection of samples with a swab in the nasopharyngeal and oropharyngeal areas to perform reverse transcription-polymerase chain reaction (RT-PCR) for viral RNA detection. However, this collection results in direct interaction between the health care professional and the suspected infected patient, exposing them to greater risk of virus transmission. In addition, this type of collection can be painful for the patient and pose the risk of bleeding. On the other hand, a non-invasive diagnosis made through saliva samples would only require patients to collect saliva in a sterile container $[6,7]$.

\section{Forms of COVID-19 transmission}

As previously stated, COVID-19 is a highly transmissible infectious disease and, according to the WHO, the main forms of this virus transmission are through droplets of saliva and/or nasal discharge from an infected patient, which can spread through the environment by coughing or sneezing [11].

A 2020 study evaluated the stability of SARS-CoV-2 in aerosol and on hard surfaces, such as plastic, stainless steel, copper, and cardboard. The authors concluded that transmission is also possible by these contaminated surfaces, since the virus remains stable and viable for infection for hours in aerosol (about 3 hours) and on the surfaces for days (about 72 hours), depending on the surface material and environment conditions [12].

The risk of transmission from asymptomatic patients is another major concern in this pandemic. A study, which evaluated the patient records from a Chinese province, estimated the period between contamination and onset of coronavirus symptoms. The estimated date of onset of the patient's symptoms and who infected them were assessed, as well as the likely location and how the infection of both patients occurred. The authors noticed that in many cases, the first patient to show symptoms was infected by an asymptomatic person who carried the virus. Therefore, they call attention to asymptomatic patients who can also transmit diseases [13].

Professionals, who work in direct contact with the face, eyes, ear, nose, and mouth, especially if aerosols are produced to perform any clinical procedure, have increased risk. For dental surgeons, for example, this risk is due to the close proximity to the patient's face and oral cavity, in addition to potential contact with saliva, blood, and other fluids. Professionals can become contaminated by inhalation of the virus spread out by aerosol, or by direct contact with contaminated dental material or instruments used on the patient $[14,15]$.

The figure 1 shows the main professions with the highest risk of exposure to COVID-19 in a study that

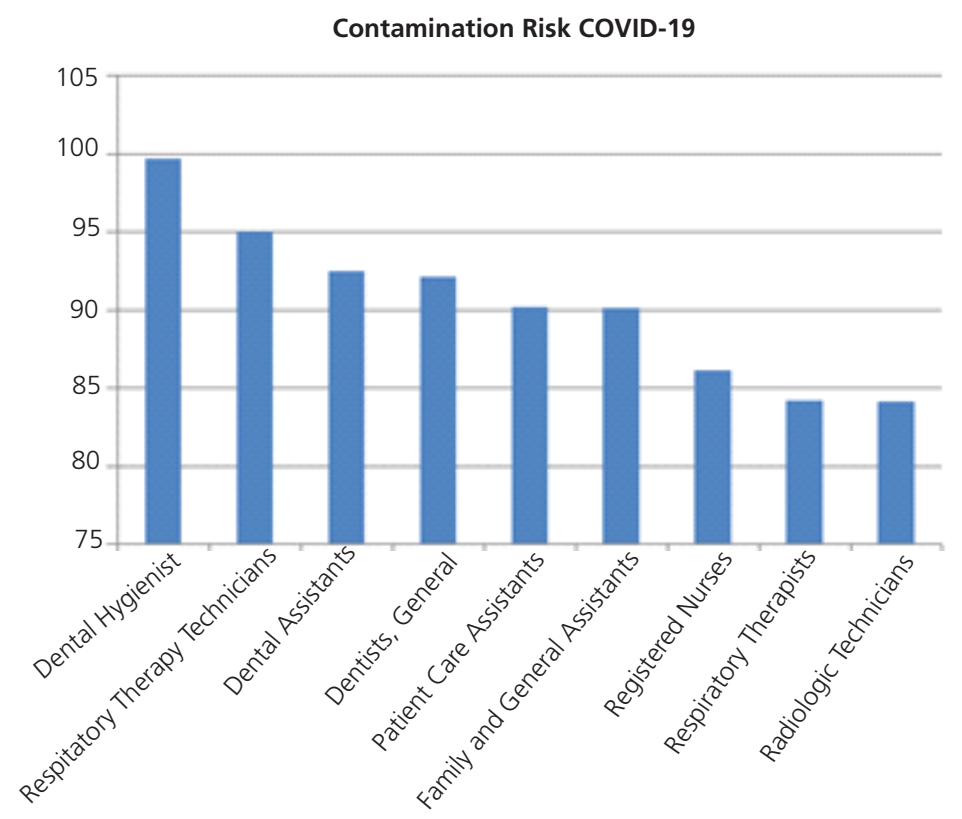

Figure 1. Main professions with the highest risk of exposure to COVID-19.

Source: Lu et al. [16]. 
correlated the main risk points: physical proximity, exposure to disease and infection, and contact with other people [16].

\section{Saliva}

Human saliva mainly consists of water with small portions of organic and inorganic molecules. In addition to maintaining oral homeostasis, saliva plays other important roles, such as participating in the digestion of food and lubrication of the oral mucosa. For microorganisms, saliva is an ecological environment that allows colonization and development. However, it also inhibits overgrowth to maintain homeostasis [17].

Several microorganisms have been identified in the saliva that can cause oral and systemic diseases, for example, zika virus [18] and coronavirus [19]. Thus, the saliva has become a vector with elevated potential for disease transmission, as well as an important ally in the monitoring and diagnosis of COVID-19 patients.

\section{Forms of COVID-19 diagnosis}

The recommended sample for the diagnosis of respiratory infections is collection of nasopharyngeal or oropharyngeal mucous secretions with a cotton swab. These areas of collection allow epithelial cells to be obtain from the region [20], then RNA extraction run and these cells analyzed [21]. However, during the sample collection procedure in addition to the patient's discomfort, the health care professional has a high risk of contamination due to bleeding that may occur. Therefore, different ways of sample collection that allow the diagnosis and monitoring of COVID-19 have been proposed, such as sputum collection. However, despite being less invasive, not all patients can produce enough secretion for collection [22].

Thus, saliva collection was thought of as it is less invasive and more easily acquired. To and Yip et al demonstrated in a 2019 article that saliva has high sensitivity and specificity for the detection of respiratory viruses. Thus, this method of collection and diagnosis reduces discomfort for the patient, is faster, has lower costs, and reduces the risks of contamination to health care professionals [23].

\section{Forms of diagnosis through saliva}

Since COVID-19 was identified in the saliva of infected patients, it became a possible alternative to

\begin{tabular}{lll}
\hline Name & Method & \multicolumn{1}{c}{ Cost } \\
\hline Antibody Testing [24] & Specific antibodies for SARS-CoV-2 in saliva & $\begin{array}{l}\text { Unviable, since the possibility of interaction } \\
\text { with coronavirus variations becomes a } \\
\text { limiting factor. }\end{array}$ \\
\hline $\begin{array}{l}\text { RT-PCR microfluidic devices } \\
\text { (on-chip lab) [28] }\end{array}$ & $\begin{array}{l}\text { This test works from a small chip composed of microchannels that process } \\
\text { liquid samples through micro heaters and microelectrodes, to extract }\end{array}$ & $\begin{array}{l}\text { Low cost and possibility of large-scale } \\
\text { DNA, in addition to amplification of the polymerase chain reaction and } \\
\text { cell lysis. }\end{array}$
\end{tabular}
cell lysis.

The LAMP Reverse Transcription Test (RT-LAMP) was created to better detect SARS-CoV-2.

Saliva samples are analyzed, where the sample is deposited in a tube and the amplified DNA is evaluated through turbidity, color, or fluorescence.

Loop-mediated isothermal amplification (LAMP) tests [25]
\#PARECOVID [26] is a cooperation between Sírio-Libanês Hospital and the company Mendelics. In this protocol, the viral RNA is converted into DNA. Then, the LAMP technique promotes virus amplification. This test can be performed directly on the saliva sample to obtain results within $24 \mathrm{~h}$

EasyCOV [27] does not require RNA extraction. This test has already been tested and proved effective in a study that included 123 patients. It requires only 200 microliters of saliva that comes in contact with an inactivating saliva solution and is incubated for $30 \mathrm{~min}$ at 65 degrees. After that, the protocol requires that $3 \mu$ of the now inactive saliva pass through $17 \mu$ of RT-LAMP for another $30 \mathrm{~min}$ at $65^{\circ} \mathrm{C}$. Finally, $1 \mu \mathrm{l}$ of SybrGreen is added to the mixture, and if the color changes to yellow, the result for the presence of coronavirus is positive, if it changes to orange, the result is negative.
Up to 95 reais ( $\$ 17$ dollars)

Kit with 35 tests for 20 euros. ( $\$ 23$ dollars) 
determine whether a non-invasive diagnosis through saliva is a viable and better approach to detect coronavirus and reduce its spread [24].

From its beginning, the scientific community around the world has been seeking solutions to continuously speed up diagnostic results of this disease. Contemplating that, several theories were formulated and many of them were put into practice aiming for a more accessible and faster diagnosis through the analysis of saliva samples, mainly for use in non-hospital environments such as dental clinics. Some suggested forms of diagnosis through saliva are demonstrated on the table [2,24-27]:

The new methods to detect the virus and to prevent contagion of both the patient and the health care professional in a practical way are improving. The diagnostic industry is developing methods for the patient to perform their own collection of saliva at home with online supervision and then send the sample to the laboratory for analysis [29].

Ongoing studies are seeking ways to optimize the collection and processing of saliva because it was observed that a large number of patients diagnosed with COVID-19, symptomatic or not, have thick saliva. This alteration in the saliva makes it harder to handle especially during pipetting procedures and requires the use of diluting reagents (especially for larger volumes of saliva). This extra saliva processing step can compromise the final assay result as the saliva is exposed to the environment for a longer time increasing the risk of contamination by the environment. Thus, studies are testing the effectiveness of special devices for collecting saliva, which can facilitate the standardization of the collected volume enabling the addition of a preservative solution, that prevents the degradation of viral RNA during the sample transport and promotes its dilution to make processing easier [30].

\section{DISCUSSION}

Currently, new biosafety measures have been implemented in the dental office routine to prevent the spreading of coronavirus. The third edition of the BIMAV FCD (Brazilian Intensive Medicine Association/Federal Council of Dentistry) Recommendations manual for facing Covid-19 in Dentistry (most updated version to date), advises postponing elective treatment of patients with or without suspected COVID-19 diagnosis, replacing intraoral radiographs with extraoral radiographs exams to prevent coughing and increased salivation. It also recommends the use of N95/PFF2 masks without valves, a waterproof apron, eye and facial protection when dental urgency/emergency care is required [31].

There are several theories about how the coronavirus can be found in saliva. The Zhou et al. [32] study completes the research done by Zhu et al [32] by elucidating the already known infection of the virus present in the respiratory tract. Thus, Silva and Jardim et al. [24] expanded this data by showing that the coronavirus present in the respiratory tract of infected individuals can invade the oral cavity by frequent exchange of droplets contaminated with virus between these organs. It is already known that bacteria present in the oral cavity can enter the organism through the gingival sulcus during routine dental procedures or even when one is performing oral home care, as well as the microorganism exchanges from the gingival crevicular fluid, as explained by Silva-Boghossian et al. [33] and emphasized by Kurita-Ochiai and Yamamoto [34]. Based on these data, Silva and Jardim et al [24] deepened our knowledge by explaining the crevicular fluid exchange is a via for contaminated blood to come into contact with the oral cavity and consequently be found in saliva.

Finally, studies such as Liu et al. [35] demonstrated that the epithelial cells of the salivary glands are one of the viral infection targets, including coronavirus, corroborating the previously mentioned studies on how the virus can reach saliva.

Dental surgeons are the professionals considered to be at highest risk of contagion due to frequent exposure and aerosol production in the dental office environment. Despite the recommended biosafety precautions, there is still a risk of contagion and the patient may have the virus, but be in the asymptomatic phase. Because of this, for the safety of both the dentist and the patient, tests for virus detection should be implemented before any dental appointment. However, the currently available tests require laboratory time and more costs, which leads to the need to develop faster and more accessible diagnostic tests based on saliva to be used at the dental office $[24,25]$.

On the other hand, doubts remain about the effectiveness of using saliva in the diagnosis of COVID-19, as is the case of the study carried out by Lee et al. [36] in which the viral load results using the sputum collection and standard nasopharyngeal and oropharyngeal collection with swabs were compared to saliva. The evaluation was based on the real-time reverse transcription-polymerase 
chain reaction ( $\mathrm{rRT} T \mathrm{PCR}$ ) assay aiming to detect the envelope $\mathrm{E}$ protein and RNA-dependent RNA polymerase (RdRp) genes. As a result, the authors observed that the sensitivity of rRT-PCR assay using saliva was significantly lower than using swabs, especially in patients who were unable to produce an adequate amount of sputum. However, higher sensitivity using saliva samples was observed in more advanced disease cases, thus having low sensitivity in the initial phase of the disease. In general, the authors suggested that saliva can be used for rapid screening or an additional test but not to substitute the conventional swab test.

Interestingly, in a similar study to Lee et al. [36], Rao et al. [37] compared the efficacy of the salivary tests performed by the patient (more specifically in the morning) to the conventional swab samples collected by health professionals. In this study, as in the previous one, the rRTPCR assay aiming to detect the envelope E protein and RdRp genes was performed and the results were compared.

The main difference between both studies is that in the last one the detection level of SARS-CoV-2 was considerably higher using saliva than using swabs. This result led the authors to conclude that the tests performed by saliva collection are a better alternative for the detection of the new coronavirus, especially due to the advantages of the collection method, such as easier sample collection (which can be performed by the patient) and lower risk of contagion.

Both works raised hypotheses concerning the possible causes of the divergent data between studies. Some studies support the standard collection using swabs, showing more reliable results [38] [39]. Another study that found the superiority of saliva collection compared to the standard swab collection [40], and other studies have demonstrated equivalent results between the diagnosis using saliva or swabs $[41,42]$.

The probable reasons for these divergences between studies may be due to differences in the evaluated populations, the method of detection, stage of disease severity, or even different sampling techniques. [37]

Despite the high risk of contamination of the oral health professionals, in Brazil, the Federal Council of Dentistry (FCD) reported that this group presents the lowest number of contaminated people among the health care professionals who are at the front line against coronavirus. Since the beginning of the pandemic, several updates, practical biosafety manuals, and protocols for disinfection of the dental clinic area have been published with several recommendations to professionals. The president of the FCD attributes the safety measures established from the beginning of the pandemic to the present moment as responsible for the low number of contaminated dentists [43]. These practical recommendations for dentists, coming from the worldwide effort to prevent the transmission of SARS-CoV-2, advised and in some cases forced dentists to postpone elective care for a certain period. Napimoga and Freitas, in 2020, [44] reported that the uncertainties about the mode of action of the virus were motivators for routine dental care suspension by clinics as recommended by the governments of several countries.

Despite the use of personal protective equipment, the uncertainty about the characteristics of the virus, such as its incubation time, asymptomatic patients, and reinfection risk of patients, can pose great risks for the dental staff. Attending only in urgent cases or suspending all appointments were fundamental attitudes for protecting the dental staff.

Articles published on this topic were important disseminators of information and, therefore, contributed to the reduction of contamination of health professionals [44]. It is extremely important to understand that a shared common area presents itself as a way for disease transmission. Thus, use of environmental and hand hygiene protocols is required to reduce the risk of contamination of dental professionals [45].

The practical guides and manuals published by private practice and dental school clinics present guidelines for reducing and controlling production of aerosols and, consequently, reducing contamination risks. Some of the guidelines are the use of high-power suction, option for absolute isolation/rubber dam, avoid the water/spray combination of the triple syringe, and use of manual instruments for removing caries and calculus. In addition, several other protocols and guidelines have been published for receiving patients, surgical attire usage and disposal, and cleaning and disinfecting the environment $[30,46]$.

\section{CONCLUSION}

Dental professionals are exposed to the risk of contamination by COVID-19, as they are in frequent proximity to the patients' face and, consequently, with saliva, 
blood, and the aerosol produced by dental procedures. Therefore, diagnostic methods are need for use before the dental appointment, to protect patients, dentists, and staff, especially in asymptomatic cases.

Thus, a scientific race is focused on the discovery and improvement of diagnostic methods, especially using saliva, and the launching of new platforms that are increasingly accessible and effective for both the collection and processing of saliva. This diagnosis would be simpler and faster in comparison to standard tests.

\section{Collaborators}

NMV MOURA and AF GONZALEZ, planning, searching and interpreting data and writing the article. M TABA JUNIOR, advisor, conceptualization, writing-reviewing the article.

\section{REFERENCES}

1. Guo Y, Cao Q, Hong Z, Tan Y, Chen S, Jin H, Tan K, Wang $Y$, Yan $Y$. The origin, transmission and clinical therapies on coronavirus disease 2019 (COVID-19) outbreak - an update on the status. Military Med Res. 2020;7:11. http://dx.doi. org/10.1186/s40779-020-00240-0

2. Xavier AR, Silva JS, Almeida JPCL, Conceição JFF, Lacerda GS, Kanaan S. COVID-19: manifestações clínicas e laboratoriais na infecção pelo novo coronavírus. J Bras Patol Med Lab. 2020;56:e3232020. https://doi.org/10.5935/16762444.20200049

3. World Health Organization. Dashboard E. Covid-19 Response Fund Europe Covid-19 Response Fund Eastern Mediterranean Africa Western Pacific. 2020 [cited 2020 Nov 10]. Availabele from: <https://www.who.int/emergencies/ diseases/novel-coronavirus-2019/donate>.

4. Arias-Reyes C, Zubieta-DeUrioste N, Poma-Machicao L, Aliaga-Raduan F, Carvajal-Rodriguez F, Dutschmann M, et al. Does the pathogenesis of SARS-CoV-2 virus decrease at highaltitude? Respir Physiol Neurobiol. 2020;277:103443. http:// dx.doi.org/10.1016/j.resp.2020.103443

5. Lau SK, Woo PC, Li KS, Huang Y, Tsoi HW, Wong BH, et al. Severe acute respiratory syndrome coronavirus-like virus in Chinese horseshoe bats. Proc Natl Acad Sci U S A. 2005 Sep 27;102(39):14040-5. http://dx.doi.org/10.1073/ pnas.0506735102

6. Fini MB. Oral saliva and COVID-19. Oral Oncol. 2020;108:104821. http://dx.doi.org/10.1016/j.oraloncology.2020.104821

7. Han P, Ivanovsky S. Saliva - Friend and Foe in the COVID-19 Outbreak. Diagnostics. 2020; 10(5):290. http://dx.doi. org/10.3390/diagnostics10050290

8. Saccucci M, Di Carlo G, Bossù M, Giovarruscio F, Salucci A, Polimeni A. Autoimmune diseases and their manifestations on oral cavity: diagnosis and clinical management. J Immunol Res. 2018 27;2018:6061825. http://dx.doi. org/10.1155/2018/6061825

9. ClarksonE,MashkoorF,AbdulateefS. Oralviral infections: diagnosis and management. Dent Clin North Am. 2017 Apr;61(2):351-363. http://dx.doi.org/10.1016/j.cden.2016.12.005.

10. Yan K, Agrawal N, Gooi Z. Head and neck masses. Med Clin North Am. 2018;102(6):1013-25. https://doi.org/10.1016/j. mcna.2018.06.012

11. Symptoms OP. Coronavirus. 2020 [cited 2020 Nov 10]. Availabele from: <https://www.who.int/health-topics/ coronavirus\#tab=tab_1 $>$.

12. Van Doremalen $N$, Bushmaker $T$, Morris DH, Holbrook MG, Gamble A, Williamson BN, et al. Aerosol and Surface Stability of SARS-CoV-2 as Compared with SARS-CoV-1. N Engl J Med. 2020 Apr 16;382(16):1564-1567. https://doi.org/10.1056/ NEJMc2004973

13. Du Z, Xu X, Wu Y, Wang L, Cowling BJ, Meyers LA. The serial interval of COVID-19 from publicly reported confirmed cases. Du Z, Xu X, Wu Y, Wang L, Cowling BJ, Meyers LA. The serial interval of COVID-19 from publicly reported confirmed cases. medRxiv [Preprint]. 2020 Mar 20:2020.02.19.20025452. https://doi.org/10.1101/2020.02.19.20025452.

14. Peng $X, X u X$, Li $Y$, Cheng L, Zhou X, Ren B. Transmission routes of 2019-nCoV and controls in dental practice. Int J Oral Sci. 2020;12:1-6. https://doi.org/10.1038/s41368-020-0075-9

15. Kampf G, Todt D, Pfaender S, Steinmann E. Persistence of coronaviruses on inanimate surfaces and their inactivation with biocidal agents. J Hosp Infect. 2020 Mar;104(3):246251. https://doi.org/10.1016/j.jhin.2020.01.022

16. Lu M. The front line: visualizing the occupations with the highest COVID-19 risk. Chinese Stud Hist. 2020;17(1):3.

17. Li $Y$, Ren B, Peng $X, H u T$, Li J, Gong T, et al. Saliva is a non-negligible factor in the spread of COVID-19. Mol Oral Microbiol. 2020 Aug;35(4):141-145. https://doi.org/10.1111/ omi.12289

18. Barzon L, Pacenti M, Berto A, Sinigaglia A, Franchin E, Lavezzo $E$, et al. Isolation of infectious Zika virus from saliva and prolonged viral RNA shedding in a traveller returning from the Dominican Republic to Italy, January 2016. Euro Surveill. 2016;21(10):30159. https://doi.org/10.2807/15607917.ES.2016.21.10.30159

19. To KK, Tsang OT, Yip CC, Chan KH, Wu TC, Chan JM, et al. Consistent detection of 2019 novel Coronavirus in saliva. Clin Infect Dis. 2020 Jul 28;71(15):841-843. https://doi. org/10.1093/cid/ciaa149

20. To KK, Chan KH, Li IW, Tsang TY, Tse H, Chan JF, et al. Viral load in patients infected with pandemic H1N1 2009 influenza A virus. J Med Virol. 2010 Jan;82(1):1-7. https://doi. org/10.1002/jmv.21664

21. Chan JFW, Yuan S, Kok KH, To KKW, Chu H, Yang J, et al. A familial cluster of pneumonia associated with the 2019 novel coronavirus indicating person-to-person transmission: a study of a family cluster. Lancet. 2020;395(10223):514-23. https:// doi.org/10.1016/S0140-6736(20)30154-9 
22. Huang C, Wang Y, Li X, Ren L, Zhao J, Hu Y, et al. Clinical features of patients infected with 2019 novel coronavirus in Wuhan, China. Lancet. 2020;395(10223):497-506. https:// doi.org/10.1016/S0140-6736(20)30183-5

23. To KKW, Yip CCY, Lai CYW, Wong CKH, Ho DTY, Pang PKP, et al. Saliva as a diagnostic specimen for testing respiratory virus by a point-of-care molecular assay: a diagnostic validity study. Clin Microbiol Infect. 2019;25(3):372-378. https://doi. org/10.1016/j.cmi.2018.06.009

24. Sabino-Silva R, Jardim ACG, Siqueira WL. Coronavirus COVID-19 impacts to dentistry and potential salivary diagnosis. Clin Oral Investig. 2020 Apr;24(4):1619-1621. https://doi.org/ 10.1007/s00784-020-03248-x

25. Sharma S, Kumar V, Chawla A, Logani A. Rapid detection of SARS-CoV-2 in saliva: can an endodontist take the lead in point-of-care COVID-19 testing? Int Endod J. 2020 Jul;53(7):1017-1019. https://doi.org/10.1111/iej.13317

26. Covid P. DE detecção. 2020 [citado 10 Nov 2020. Disponível em: $<$ https://www.mendelics.com/assets/PareCovid_Informacoes_ Atualizacao1506.pdf>.

27. L'Helgouach N, Champigneux P, Schneider FS, Molina L, Espeut J, Alali M, et al. EasyCOV: LAMP based rapid detection of SARS-CoV-2 in saliva. Medrxiv. 2020. https://doi.org/ 10.1101/2020.05.30.20117291

28. Zhu N, Zhang D, Wang W, Li X, Yang B, Song J, et al. China Novel Coronavirus Investigating and Research Team. A Novel Coronavirus from Patients with Pneumonia in China, 2019. N Engl J Med. 2020;382(8):727-733. https://doi.org/10.1056/ NEJMoa2001017

29. Test OA. COVID-19 test kit. 2020;1-17 [cited 2020 Nov 12]. Availabele from: <https://www.vaulthealth.com/covid>.

30. Landry ML, Criscuolo J, Peaper DR. Challenges in use of saliva for detection of SARS CoV-2 RNA in symptomatic outpatients. J Clin Virol. 2020;130:104567. https://doi.org/10.1016/j. jcv.2020.104567

31. Associação de Medicina Intensiva Brasileira. Conselho Federal de Odontologia. Recomendações AMIB/CFO para enfrentamento da COVID-19 na Odontologia. 2020 [citado 2020 Nov 12]. Disponível em: <https://website.cfo.org.br/ publicada-4a-versao-de-recomendacoes-amib-cfo-paraenfrentamento-da-covid-19-na-odontologia/>.

32. Zhou $P$, Yang XL, Wang XG, Hu B, Zhang L, Zhang W, et al. Addendum: a pneumonia outbreak associated with a new coronavirus of probable bat origin. Nature. 2020 Dec;588(7836):E6. https://doi.org/10.1038/s41586-020-2951-z

33. Silva-Boghossian CM, Colombo AP, Tanaka M, Rayo C, Xiao $Y$, Siqueira WL. Quantitative proteomic analysis of gingival crevicular fluid in different periodontal conditions. PLoS One. 2013 Oct 1;8(10):e75898. https://doi.org/10.1371/journal. pone.0075898

34. Kurita-Ochiai T, Yamamoto M. Periodontal pathogens and atherosclerosis: implications of inflammation and oxidative modification of LDL. Biomed Res Int. 2014;2014:595981. https://doi.org/10.1155/2014/595981

35. Liu L, Wei Q, Alvarez X, Wang H, Du Y, Zhu H, et al. Epithelial cells lining salivary gland ducts are early target cells of severe acute respiratory syndrome coronavirus infection in the upper respiratory tracts of rhesus macaques. J Virol. 2011 Apr;85(8):4025-30. https://doi.org/10.1128/JVI.02292-10

36. Kim SE, Lee JY, Lee A, Kim S, Park KH, Jung SI, et al. Viral Load Kinetics of SARS-CoV-2 Infection in saliva in Korean patients: a prospective multi-center comparative study. J Korean Med Sci. 2020 Aug 10;35(31):e287. https://doi.org/10.3346/ jkms.2020.35.e287

37. Rao M, Rashid FA, Sabri FSAH, Jamil NN, Zain R, Hashim R, et al. Comparing nasopharyngeal swab and early morning saliva for the identification of SARS-CoV-2. Clin Infect Dis. 2021 May 4;72(9):e352-e356. https://doi.org/10.1093/cid/ ciaa1156

38. Williams $E$, Bond $K$, Zhang B, Putland M, Williamson DA Saliva as a noninvasive specimen for detection of SARS-CoV-2. J Clin Microbiol. 2020 Jul 23;58(8):e00776-20. https://doi. org/10.1128/JCM.00776-20

39. Becker D, Sandoval E, Amin A, Hoff PD, Diets A, Leonetti N, et al. Saliva is less sensitive than nasopharyngeal swabs for COVID-19 detection in the community setting. medRxiv. 2020 May 17. doi: https://doi.org/10.1101/2020.05.11.20092338

40. Wyllie AL, Fournier J, Casanovas-Massana A, Campbell M, TokuyamaM, VijayakumarP, etal. SalivaismoresensitiveforSARSCoV-2 detection in COVID-19 patients than nasopharyngeal swabs. medRxiv. 2020;(2):2020.04.16.20067835. https://doi. org/10.1101/2020.04.16.20067835

41. Van Vinh Chau N, Lam VT, Dung NT, Yen LM, Minh NNQ, Hung LM, et al. the natural history and transmission potential of asymptomatic severe acute respiratory syndrome Coronavirus 2 infection. Clin Infect Dis. 2020 Dec 17;71(10):2679-2687. https://doi.org/10.1093/cid/ciaa711

42. Jamal AJ, Mozafarihashjin M, Coomes E, Powis J, Li AX, Paterson A, et al. Sensitivity of nasopharyngeal swabs and saliva for the detection of severe acute respiratory syndrome Coronavirus 2. Clin Infect Dis. 2021 Mar 15;72(6):1064-1066. https://doi.org/10.1093/cid/ciaa848

43. Calazans M. Cirurgiões-dentistas são os menos contaminados pela Covid-19. 2020 [citado 2020 Nov 12]. Disponível em: <https://website.cfo.org.br/cirurgioes-dentistas-sao-osmenos-contaminados-pela-covid-19/>.

44. Napimoga MH, Freitas ARR. Dentistry vs Severe acute respiratory syndrome Coronavirus 2: how to face this enemy. RGO, Rev Gaúch Odontol. 2020;68:e20200011. https://doi. org/10.1590/1981-863720200001120200034

45. Desai AN, Patel P. Stopping the Spread of COVID-19. JAMA. 2020;323(15):1516. https://doi.org/10.1001/jama.2020.4269

46. Associação Brasileira de Ensino Odontológico. Consenso Abeno: biossegurança no ensino odontológico pós - pandemia da COVID-19. 2020 [citado 2020 Nov 12]. Disponível em: <https://abeno.org.br/abeno-files/downloads/retomada-depraticas-seguras-no-ensino-odontologico.pdf $>$.

Received on: 4/8/2020

Final version resubmitted on: 4/9/2020 Approved on: 23/10/2020 